\title{
The Xinjiang Case and Its Implications from a Business Ethics Perspective
}

\author{
Alexander Kriebitz ${ }^{1} \cdot$ Raphael Max $^{1}$ \\ Published online: 22 May 2020 \\ (C) The Author(s) 2020, corrected publication 2021
}

\begin{abstract}
The discourse on economic integration with authoritarian regimes has evolved as a key topic throughout the different disciplines of social sciences. Are sanctions and boycotts effective methods to incentivize human rights improvements? To analyze this question, we focus on the situation in China's Xinjiang province from 2010 to 2019. In this paper, we discuss the relevance of human rights as an ethical norm within business ethics and international law. We evaluate the ongoing processes in Xinjiang from this perspective and scrutinize the interests of major players in the region, including the Central Government of the People's Republic of China, Xinjiang's local government, and enterprises involved in the region. Following this, we discuss which economic measures will improve the human rights situation and how these measures contribute to an improvement of the situation.
\end{abstract}

Keywords Human rights $\cdot$ Xinjiang $\cdot$ Digitization $\cdot$ China

\section{Introduction}

In the past two decades, the discourse on economic integration with authoritarian regimes has evolved as a key topic throughout the different disciplines of social sciences (Haas 1998; Hufbauer et al. 2012; Kaempfer and Lowenberg 2007; Smeets 2018). The debate primarily centers on the question of whether it is legitimate to engage in trade and commerce with regimes neglecting or even violating human rights and whether it is helpful to use sanctions and boycotts to force repressive regimes to

Alexander Kriebitz

a.kriebitz@tum.de

Raphael Max

r.max@tum.de

1 TUM School of Governance, Technical University of Munich, Arcisstr. 21, 80333 Muenchen, Germany 
improve their human rights performance (Kaempfer and Lowenberg 2007; Delacote 2009; Grauvogel and von Soest 2014). The important theoretical aspects of this matter notwithstanding, the way to interact with repressive regimes commercially revolves around very practical questions: Which measures do governments need to design to bring about change in repressive regimes? What can companies do to prevent human rights violations by authoritarian regimes?

The methods discussed include, among others, conditional trade agreements tied to human rights performance, individual companies' boycott actions, and the governmental enforcement of collective economic sanctions. Although the extent of boycott measures varies from case to case and might partly be driven by geopolitical interests, the rationale behind the actions remains largely the same: reducing economic ties to human rights violators enhances the pressure to improve human rights compliance. The sanctions against Sudan imposed in the aftermath of the Darfur Crisis or the sanctions regime on Myanmar targeting the military and state apparatus partly illustrate the relevance and impact of such human rights considerations. Are sanctions and boycotts effective methods to incentivize human rights improvements? To analyze this question, we focus on the situation in China's Xinjiang province from 2010 to 2019. The repression of the Uyghur minority in China's West has sparked a fierce debate in the human rights discourse (Thum 2018; Zenz 2019), raising the question of how companies and governments should position themselves in light of such events and whether companies should evade economic cooperation with repressive regimes (Delacote 2009; Grauvogel and von Soest 2014). Some observers have even called for a divestment campaign of international enterprises. Our contribution intends to provide a preliminary business ethical assessment of the situation in Xinjiang by scrutinizing the situation from the angle of human rights.

Our examination proceeds in the following order:

(1) We discuss the relevance of human rights as an ethical norm within business ethics and international law.

(2) We evaluate the ongoing processes in Xinjiang from this perspective and scrutinize the interests of major players in the region, including the Central Government of the People's Republic of China, Xinjiang's local government, and enterprises involved in the region.

(3) We discuss which economic measures will improve the human rights situation and how these measures contribute to an improvement of the situation.

\section{Do States Have to Adhere to Human Rights?}

The emergence of human rights as normative principles of international law traces back to the adoption of the United Nations Declaration on Human Rights in 1948 (Rosas 1995). The UNDHR provided the first extensive codification of human rights and sparked an intensive debate on the universal validity of human rights (Lauterpacht 1950). Constituting limits of state sovereignty, human rights challenge the traditional understanding of a state-centered international law. The exact relationship between state sovereignty and human rights as well as the question, whether human rights apply to states, which have not ratified human rights, has therefore initiated an ongoing 
debate in international law and business ethics (Henkin 1995; Goldsmith 2000; Caplan 2003; Gilabert 2011).

The discourse on international law and human rights is characterized by the debate between proponents arguing that human rights constrain state sovereignty and advocates of a primate of State sovereignty (cf. Reisman 1990; Habermas 1994; Henkin 1995; Frank 1997; Buergenthal 1976; Rabkin 1998; Roth 2004). The recent years however have been marked "steady drift toward human values" (Henkin 1995; cf. Jones 2018). Moreover, sovereignty is increasingly perceived as "conditional" or "relational" (Stacy 2003) in the sense of being bound by moral principles, such as human rights compliance or "good governance" (Ruggie 1993; Sen 1999; Slaughter and Burke-White 2006). This tendency traces back to the emergence of human rights treaties such as the International Covenant on Political and International Civil Rights, the Covenant on Social, Economic and Cultural Rights or the International Convention for the Protection of All Persons from Enforced Disappearance. Based on these treatises, states violate international law, when they practice genocide, slavery, extrajudicial killings or disappearances, torture or other inhuman treatment or punishment, and systematic racial discrimination (compare: Henkin 1995; D’Amato 2010; Murphy \& Johnson 2004). Moreover, international treatises have defined proportionality as a general principle of State action, implying that state actions ought not to be excessive, provided or prescribed by law and must pursue a legitimate aims (compare: Silver and others v. the United Kingdom ECHR 25 Mar 1983).

Although international treatises constrain state action, it remains unclear whether adherence to human rights apply to actors, who refute the concept of human rights (cf: Baderin 2003; Corlatean 2019) or who did not ratify relevant human rights treaties. ${ }^{1}$ Literature typically distinguishes here between universalists, who claim that human rights are applicable throughout time and space, and cultural relativists, who posit that the normative relevance of human rights depends on cultural and developmental features (cf: Donnelly 1984; Frank 1997). Business and human rights discourse leans towards a universalist understanding of human rights. Notable approaches include John Rawls' Law of People (Rawls 2001), Amartya Sen's "Democracy as a Universal Value," and more recently in the works of Wettstein (2015), who has argued that adherence to human rights constitutes "an agent-neutral responsibility, which applies to every individual and every organized collectivity." A mediating position between moral universalism and the understanding that legal principles evolve in a historical process (cf. Douglass North 1981, 1991) might be the concept of "hypernorms" (Donaldson and Dunfee 1999), which refers to cross-culturally demonstrated moral principles such as human rights. The idea of "hypernorms" fits in to the position of many legal scholars, who posit that human rights form an elementary part of international customary law (Simma and Alston 1992; Henkin 1995). Rulings of the International Court of Justice and national constitutional courts (D'Amato 2010; McCrudden 2015) have largely confirmed the role of basic human rights principles within customary law (Crawford and Keene 2019), which provides a strong grounding for a universal prohibition of systematic racial discrimination, torture, disappearances, or slavery (D'Amato 2010). A cornerstone in the elevation of human rights as a

\footnotetext{
${ }^{1}$ The International Covenant on Civic and Political Rights has not been ratified a sizeable number of UN members including the People's Republic of China.
} 
normative principle has been "The Responsibility to Protect doctrine," which has been widely backed up by the UN General Assembly and which explicitly states that "each individual State has the responsibility to protect its populations from genocide, war crimes, ethnic cleansing and crimes against humanity." The notion of human rights set forth in the Responsibility to Protect Resolution links up to an understanding of human rights that binds all subjects of international law, irrespective of the fact whether they have signed human rights treaties or not (cf. Cohen and Deng 1998).

\section{Who Is Responsible for Human Rights Violations?}

The increasing acceptance of human rights as normative principles within international law has shifted the debate to the question of human rights responsibility. In line with the United Nations General Principles on Business and Human Rights, we differentiate between duties of States and responsibility of enterprises.

\section{Duties and Measures of States}

In 1970, International Court of Justice has clarified the role of states as protectors of human rights arguing that "principles and rules concerning the basic rights of the human person" constitute obligations of the State "towards the international community as a whole (ICJ 1970)." More recent interpretations of international law have expanded the "responsibility to react" to human rights violations outside of the territory (ICISS 2001). The Responsibility to Protect principle refers here to "appropriate diplomatic, humanitarian and other peaceful means to deter and prosecute human rights violations," which finally legitimizes governments to take coercive measures directed against human rights violators (cf: De Hoogh 1996). The exact extent of these measures, however, is fiercely contested based on legitimacy and efficacy concerns. Many scholars (e.g., Hufbauer et al. 1990; Dashti-Gibson et al. 1997; Levy 1999; McMahon 2006; Gordon 2011) have argued that indiscriminate sanctions are largely ineffective and that they might result in complex ethical questions. The debate has therefore shifted to smart sanctions, which address perpetrators directly (Gordon 2011). One major example is the US Global Magnitsky Act, which allows "the President to impose sanctions with respect to any foreign person [...] responsible for gross human rights violations or acts of significant corruption." Although research on the Global Magnitsky Act has highlighted the act's positive effects on human rights (compare: Firestone and Contini 2018), critics of smart sanctions question the concept in terms of practicability, conflicts of interests, and logistical issues (cf. Drezner 2011; Gordon 2011).

Based on the United Nations Guiding Principles on Business and Human Rights, we can derive an alternative strategy to foster human rights. The UNGPs call on States to "enforce laws that are aimed at, or have the effect of, requiring business enterprises to respect human rights, and periodically to assess the adequacy of such laws and address any gaps." Following this logic, states are encouraged to engage in more general legislation aiming at the regulation of domestic companies in countries with human rights issues (compare UNGP I. 2). Prominent examples for extraterritorial legislation are the UK Modern Slavery and Human Trafficking Act, obliging multinationals to 
disclose measures taken to prevent slavery and forced labor in their supply chain. However, some authors criticize the Act as "too weak" (Mantouvalou 2018) concluding that "business of forced labour continues to be insufficiently regulated" (LeBaron \& Rühmkorf 2017).

\section{Responsibilities of Enterprises}

Although States have traditionally been regarded as main actor of international law, the human rights discourse has recently shifted to the responsibilities of multinationals. In "Human Rights and Business Ethics: Fashioning a New Social Contract", Cragg (2000) has argued that a "tacit social contract determines the distribution of responsibility between businesses and governments," which implies the existence of human rights obligations for enterprises. Santoro (2000) has elaborated on the concept of responsibility of international companies and has established principles of human rights conduct for business operations in countries with repressive institutions. Likewise, Jägers (2002) has argued that "corporations may in some cases have a greater impact on human rights than individual States" and posed the question, which human rights obligations corporations can be expected to fulfill.

Although the idea of transferring human rights responsibilities to enterprises has been refuted by some scholars (Hsieh 2015), the UN Guiding Principles of Business and Human Rights confirmed the existence of responsibilities to companies concerning human rights. The question is rather "how extensive they are." (Wettstein 2015). The UNGP state here that enterprises are "required to comply with all applicable laws and to respect human rights" and refer here to human rights as defined by the International Bill of Rights, including both covenants. Moreover, the UNGPs, provide that companies should "identify and access any actual or potential adverse human rights impact with which they may be involved either through their own activities or as a result of business relationships."

Approaches in the post-Ruggie business and human rights literature tend to go beyond the term of mere responsibility and stress that the duties of enterprises vis-a vis human rights include "helping protect people from being deprived of their rights" (cf. Wettstein 2015). The main question here is how companies can to realize this moral obligation, given pressure from repressive governments. At the same time, it remains contentious, whether multinationals should try to actively change the situation by engaging in policies (cf. Santoro 2000; Sethi and Williams 2002) or suspend their business activities in repressive environments (cf. White 2004; De Bakker and De Hond 2010).

\section{The Division of Labor Between States and Enterprises}

Based on the current debate, we summarize the smallest common denominator of the literature on business and human rights on the division of labor between States and enterprises in dealing with human rights:

- States have a legal obligation to uphold human rights in their own territory. The legal obligations arise from conventional and customary international law.

- States have a duty to take measures to prevent human rights violations outside of their territory. Sanctions and extraterritorial legislation are means to do this. 
- Companies have the responsibility to prevent human rights breaches in their own supply chain and to enhance human rights in the society. The exact meaning of this responsibility remains subject of debate.

Keeping the theoretical debate on the division of labor between States and enterprises in mind, we analyze the ongoing situation in the case of Xinjiang and identify how to supplement the current frameworks for dealing with cases like Xinjiang. Moreover, we will evaluate what the current case implies for the general discussion on the division of labor between States and enterprises and the discourse on legal instruments and corporate measures to prevent human rights violations.

\section{What Is the Problem in Xinjiang?}

From a historic point of view, the situation in the Xinjiang dates back to the acquisition of the province by the People's Republic of China following its victory in the Chinese Civil War. Xinjiang was previously under the control of the Qing dynasty. After the end of the Chinese Civil War, the efforts of the Chinese government to sinicize Xinjiang aggravated the situation in the region. As in other cases of Communist rule, such as Afghanistan or Chechnya (Girardet 2012), imposed modernization brought about severe socio-economic conflicts within and among the different ethnicities in the region. Moreover, the measures implemented by the authorities were mainly directed against the ethnic groups of Islamic faith living in Xinjiang, namely the Uyghur, Kazak, and Kyrgyz minorities. This distinction sparked conflict based on ethno-religious lines. To curb violence and to tighten control over the province, the People's Republic has not only relied on high security expenditures but also motivated the settlement of mostly Han Chinese people from other parts of the country. According to statistics of the 2000 Population Census of China, the amount of Han Chinese living in the region has increased from 3.7\% in 1949 to $40 \%$ in 2000 (Bao 2018).

Although the repression of the Uyghur minority reached its peak during the Cultural Revolution, the suppression of socio-economic and political rights persisted during the Opening and Reform Policy in the 1970s and 1980s. Unlike other parts of mainland China, Xinjiang remained cutoff from the liberalization waves in the 1980s. Moreover, military conflicts in Central Asia in the 1980s and 1990s contributed to the radicalization of the Islamist fundamentalists in Xinjiang and generated a supply of weapons and the spreading of a fundamentalist ideology. The events in Xinjiang took a decisive turn after the July 2009 Urumqi riots and the terror attack in Kunming 2014, which resulted in a hardening stance of the Chinese Central Government on the "Uyghur question." The "Strike Hard Campaign against Violent Terrorism" (严厉打击暴力恐怖活动专项行动) of 2014 brought with it a sharp rise in arbitrary arrests of Uyghur minorities, a significant increase of the expenditure for public safety (Feng 2018) and laid the foundation for "one of the most heavily policed regions in the world" (Zenz 2019). An important pillar of the current Chinese policy are the so-called re-education camps (再教育营) established around 2017, which detain large parts of the Uyghur population. According to many observers, forced labor and inhuman conditions such as torture are commonplace in these institutions, constituting conflicts with basic human rights (Zenz 2019). 
The Chinese government has generated much evidence for the existence of the detainment camps and the securitization policy in the form of official procurement tenders of the regional government (Wen and Auyezov 2018; Thum 2018) and online published legislation. Further, pieces of evidence were produced by satellite imagery and testimonies involving even Chinese security staff members (Ryan et al. 2018). The Regulation on De-Extremification is the legal basis for the ongoing atrocities. It states “de-extremification (去极端主) shall complete work on educational transformation, implementing a combination of individual and group education; combining legal education and mentoring; combining ideological education, psychological counseling, behavioral corrections, and skills training; combining educational transformation and humanistic care; strengthening the effectiveness of educational transformation (Art. 14)." Although the government has repeatedly portrayed the camps as "vocational training centers," witness reports and the sheer scale of the detained population suggest something else. According to recent estimates, the number of persons detained amounts to 10 or $11.5 \%$ of Xinjiang's Muslim population (Thum 2018), while the US bill on the Xinjiang situation puts the number of detained Uyghurs at 1,000,000. Given the extraordinarily high numbers of ethnic minorities of Muslim faith in these camps, the camps' existence and the institutionalized discrimination of Muslims likely constitute a violation of the UN Universal Declaration on Human Rights, as well as the AntiApartheid Convention (cf. Art. 2 a iii).

The measures of the Chinese government not only encompass traditional forms of repression but also involve state-of-the-art technologies, such as AI, which accesses biodata and DNA databases and is linked for face recognition. According to a report of the New York Times (Buckley and Wong 2019), Chinese start-ups have been involved in the establishment of algorithms to monitor ethnic Muslims in China's Xinjiang province. This involvement has sparked criticism of several NGOs and governmental groups (cf. European External Action Service 2018) and international organizations (cf. UN OHCHR 2019). The fact that the members of ethnic minorities are generally placed under suspicion, the violations of the right to physical integrity and equal treatment (such as Art. 18/19/21/29 of the Counterterrorism Law of the PRC or the "Regulation on De-Extremification") and the low legal threshold for detaining individuals (UN OHCHR 2019; Zenz 2019; Thum 2018) seem to confirm this view. The Regulation on De-Extremification states that institutions should "actively guide religions to become compatible with socialist society (Art. 4)," hinting at the interest of the Chinese government to sinicize Xinjiang. The Regulation on De-Extremification outlaws the "wearing, or compelling others to wear gowns with face coverings or to bear symbols of extremification" (Art. 9). Based on the quantity and quality of these human rights violations, we conclude that the situation in Xinjiang constitutes a violation of elementary human rights, as described in the International Bill of Human Rights.

\section{The Political Economy of Human Rights Violations in Xinjiang}

The extent of the human rights violations in China's border region begs the question why China's government is targeting the minorities of Islamic faith in Xinjiang to such an extent. Moreover, policy measures addressing human rights violations require an understanding of the political economy of human rights violations. In the following, we 
present therefore the role and interests of the different stakeholders involved in the human rights violations. The major finding of our research is that economic and political interests of national and local decision-makers determine the human rights violations originating in Xinjiang.

\section{Economic Growth and Political Legitimacy}

The notion of economic growth triggered by the expansion of commercial ties plays an important role for the political legitimation of the rule of the Communist Party and explains the interest in the Chinese administration to provide safety in the region. In contrast to the early Mao Era, which was characterized by a "charismatic leadership style" in the sense of Max Weber (Tang 2016), the legal reforms under Deng Xiaoping have strengthened the role of the socio-economic rights and professionalized the Chinese state apparatus (Dou and Deng 2019). The paradigm shift in leadership style has also affected the justification of the Communist Party and strengthened the role of socio-economic performance- " "the fundamental interests of the greatest majority of the people" as part of the Three Representations under Jiang Zemin (Mohanty 2003). Hence, the legitimacy of the Chinese leadership depends critically on the economic performance of the country (Tang 2016) and the support of influential groups within the central government including the Party, the Military, influential business people and the state-administration. As a result, safeguarding access to resources for these supporting regime groups and fostering trade links constitute pivotal aspects of the decision-making process in Zhongnanhai. Keeping growth rates steady is crucial for both goals: Economic growth reduces the risk of distributional conflicts, which might split the supporting coalition of the regime (cf. Feng 1997), and strengthens its legitimacy within the population (Tang 2016).

\section{The Stakes of the Central Government in Xinjiang}

Due to the constitutional setup of the People's Republic as a heavily centralized state and given the strong linkage between the Chinese Communist Party and the state bureaucracy, the central government plays an essential role in the context of human rights abuse in the Xinjiang province. For instance, the CPC Central Committee is able to appoint the party secretaries of the provinces and autonomous regions, which wield more influence than local governors do. Likewise, the regular exchange of party secretaries such as Chen Quanguo, who regularly switch provinces, strengthens the role of the party within the provinces and increases the accountability of the provinces to the center (Goodman 1980; Economist 2017; Foreign Policy 2019). The main interests of the Chinese central government appear to be controlling resource-rich areas, establishing a strategically important foothold in Central Asia and preventing the further independence of areas such as Tibet or Hong Kong. Some researchers even opine that the region suffers from the resource curse syndrome, as a result of an asymmetric economy (Hong and Wenhui 2018) and the affluent energy sector. According to recent estimates, Xinjiang is among the most resource-rich territories in China, possessing $40 \%$ of coal, $22 \%$ of petroleum, and $28 \%$ of gas reserves in the country (Wong 2014; Hong and Wenhui 2018). As a result, Xinjiang's abundant resources attract the interests of state-owned companies in the mining and refinery 
sector. The existence of these resources is also important to guarantee some degree of self-sufficiency for the Chinese economy in terms of energy proliferation, as the Chinese industry generally depends on natural resources and has emerged as the second largest petroleum consumer after the USA. The economic rationale behind the policies is also evident within the Chinese government's official publications on the matter. The White Paper on Vocational Education and Training in Xinjiang of 2019 has emphasized that the security measures are aimed at protecting economic development rights (发展权) and at raising “the economic and social development level of the region” (经济 社会发展水平). This links to the above mentioned legitimacy concept of the Chinese government as the guarantor of stability and economic progress. Another important factor, which is relevant for the Chinese leadership, is the location of the province on the Silk Road connecting the Chinese heartland with Russia, the Middle East, and Central Asia. Recently, China has put a strong emphasis on revitalizing the Silk Road in order to gain influence in the region and in order to improve the economic performance of the region. The 13th Five-Year Plan of the People's Republic has stated its goal to develop "Xinjiang as the core region for the Silk Road Economic Belt" (OECD 2018) and highlighted its relevance in the context of the China-Pakistan Economic Corridor, which forms an essential part of the one belt-one road strategy (一带一路). Another important factor behind the considerations of the Chinese government is its potential spillover role for other critical regions such as Tibet, inner Mongolia, or Hong Kong. Keeping control over this region and minimizing tensions, therefore, plays a pivotal role for the central leadership in Beijing. Moreover, the extensive measures of the Chinese government to control the area seem to be motivated by past terror attacks and independence movements. The uproar in Urumqi in 2009 and terror attacks in Kunming in 2014 illustrate the discontent of many Uyghur with the Chinese leadership and the existence of terrorist groups with the aim to erect an Islamic caliphate in the area. The terror attacks can also be seen in the greater context of radical Islamism, due to the presence of international terror organizations in Xinjiang (Wen and Auyezov 2018). Consequently, Uyghur resistance against the central government is labeled as one of the "five poisons" - along with the Tibetans, Uyghur Muslims, democracy activists and pro-independence Taiwanese, and Falun Gong practitioners. These "poisons" threaten the primate of the Communist Party (Economist 2018). The presence of similar paramilitary units, namely the People's Armed Police, in all three areas-Hong Kong, Tibet, and Xinjiang-illustrates that the Chinese leadership considers them as an interdependent problem.

\section{Involvement of Local Level Decision-Makers}

Although the interests of these local groups might play only a minor role due to the overwhelming strength of the central government, local decision-makers are involved in the implementation of the guidelines set up by the central government and have significant competencies in legislation and execution. Legislation, which forms the basis of the Uyghur repression in Xinjiang, was passed by the XUAR as well (e.g., "Xinjiang Uyghur Autonomous Region Regulation on the Application of the AntiTerror Law of the People’s Republic of China” [新疆维吾尔自治区实施<中华人民共和国 反恐怖主义法>办法]; Xinjiang Uyghur Autonomous Region Act on De-Extremification [新疆维吾尔自治区去极端主义条列]). Moreover, the Xinjiang Uyghur Autonomous 
Region's actions seem to be backed by different interest groups who profit from the repression against Uyghurs in different ways. These include co-opted Uyghurs who stand to profit from a closer integration with China (Zenz 2019), Han Chinese locals profiting from the exclusion of ethnic Uyghurs from socio-economic rights, stateowned enterprises maintaining business operations in the area, and private companies involved in the security sector.

\section{Distribution Conflicts and Land Grabbing in the Private Sector}

Reports of expropriation of Uyghurs surfaced in 2013 and point to distribution conflicts between Han Chinese settlers and native Uyghurs. According to several reports (Radio Free Asia 2013; De Jong 2010), Uyghur settlers were forced to give up farming land, fearing expropriation by the government with unjust cause or even without compensation. The issues depicted here might differ from typical cases of land grabbing disputes, as it is not the land per se which is scarce, but rather the access to resources like water and arable land. Artificial irrigation is crucial for the water intensive cotton industry, which depicts one of Xinjiang's most important cash crops (United Nations Environment Programme 2002; Appiah et al. 2014). The demolition of Uyghur farmers' assets and property, however, is often aimed not only at redistributing land to the Han Chinese population but also at dislocating Uyghurs from traditional social structures (Zenz 2019).

\section{Sinicization and Han Chinese Employment}

The region's sinicization is largely a goal of the central government, but it nurtures the emergence of groups with stakes in perpetuating the status quo, in this case the Han Chinese. Considering the strong Han Chinese presence in public administration and troops stationed in the area, the Han Chinese appear to control the economy, leaving only a few opportunities to local Uyghur farmers and shopkeepers to participate in the economic growth of the region. This is also visible in the discrimination against Uyghurs when it comes to job offers in state-sector companies and to subsidies access (Cliff and James 2007). An overwhelming number of workers employed by the Xinjiang Production and Construction Corps (XPCC) - the major employer in the region-belong to the Han ethnicity and not to local minorities, which account for more than $64 \%$ of the province (Bao 2018). Given the inequalities between Han Chinese settlers and Uyghurs, Han Chinese and settlers pouring in from other provinces stand to profit from the economic exclusion of Uyghurs (Cliff and James 2007).

\section{Forced Labor in the Textile Industry and Agricultural Sector}

In a similar fashion, companies profiting economically from forced labor are likely to back the policies of the regime (Radio Free Asia 2019). According to reports by Chinese NGOs (Dou and Deng 2019), companies in the cotton and textile industry of the province are involved in forced labor. The involvement of state authorities in establishing links between companies creates interlinkages between private, semiprivate, and state sectors and the intertwined supply chains in the region. This involvement and the complicated links make it hard to distinguish between the private and 
forced labor economy. Moreover, the system of forced labor not only is linked to the detainment camps but also dates back to earlier practices, which involved seasonal forced work. The Uyghur term "hashar" refers to the compulsory labor of Muslim Uyghurs, a practice which was established prior to the erection of the detainment camps (Hoshur 2015). But what explains the recent turn of politics after 2017 ?

We opine that the increase in forced labor in Xinjiang is connected to the cotton price. The increasing competition from other countries such as Bangladesh and Pakistan has rendered it more difficult for ordinary Chinese companies to survive in the market (United Nation Environment Program 2002). The main factor driving the increase in Chinese cotton price was the rising cost of labor, especially after 2010 (MacDonald et al. 2015). The recent decline of Chinese cotton prices was prompted by the Chinese government's decision to expose the Chinese cotton industry to world market prices in 2014 (McDougal and Reisman 1983), which increased the pressure of local producers to cut labor costs. Given the role of forced labor in the cotton and textile industries, forced labor might have been decisive in the increasing share of Xinjiang's cotton production - contrasting to the overall trend in China - and maintaining China's leadership in the cotton. Therefore, the parallel setup of detainment camps, rising pressure on the Uyghur population and the changing economic situation for textile manufacturers, might not be a coincidence. Even if forced labor does not explain the surge of the domestic textile industry, it explains that many Chinese textile manufacturers have opted to produce in Xinjiang due to the low production costs, given the access to cheap labor. According to Dou and Deng (2019), detainees are forced to work in textile factories, which are branded as "training programs." The involvement of private companies in forced labor is also lucrative for the Chinese authorities, as Xinjiang-based companies are expected to make regular donations to the local government for policy campaigns and public security authorities (ibid.). In this sense, the state-owned sector seems to refinance the costs of supervision by levying taxes on the companies profiting from forced labor.

\section{State-Owned Enterprises, Forced Labor, and Land Grabbing}

In addition, state-owned enterprises such as the Xinjiang Production and Construction Corps stand to profit from their exclusive access to resources located in the area (Cliff and James 2007; Bao 2018). Compared to the rest of China, the importance of stateowned enterprises in the region is significantly higher, due to its strong relationship with the military and their extraordinary role within the province. According to Becquelin (2004), the percentage of industrial assets runs by state-owned enterprises amounts to more than $80 \%$. Besides the oil exploiting industry, made up by national companies such as Sinopec, the Xinjiang Production and Construction Corps represents the most important economic agent in the area and has evolved from the Chinese tuntian (屯田) system, a policy of settling military units in frontier areas that were provided with economic power. Given its extraordinary size and its monopolistic structure, about 13\% (2002) of the population of the Xinjiang Uyghur Autonomous Region are connected to the XPCC, also known as Bingtuan (Foreign Policy 2014). This connects not only to the textile and cotton industry, which is partly under the control of the Bingtuan, but also to agriculture, where land-grabbing conflicts with Uyghur farmers have been reported throughout Xinjiang's history (Seymour and 
Anderson 1999). Recently, the conflict of using water for irrigation, which plays an important role for the region's agriculture, has fostered the conflict between Uyghurs and Chinese authorities (Starr 2003). The conflict seems to be enhanced by the fact that Bingtuan operates inefficiently and has chronic financial problems. Reports have highlighted the organization's financial difficulties after the 2010s, challenging its traditional business model (Bao 2018). According to Dou and Deng (2019), the Bingtuan failed to pay back interest and principal for $\$ 73$ million onshore bonds and relied on state intervention and subsidies. Although it remains questionable to what extent the decision to build re-education camps was driven by economic considerations of the XUAR, the institution seems to benefit from forced labor. For example, the Bingtuan is directly involved to some extent with detainment camps so that it can profit from products manufactured by the Uyghurs in the camps (Perper 2019). Chinese leadership has indirectly admitted the use of forced labor. A Chinese White Paper (2019) explicitly states that mandatory re-education involves training in "garment making, food processing, assembly of electronic products, typesetting and printing, hairdressing and beauty services, e-commerce, auto maintenance and repair, interior design and decoration, livestock breeding, pomiculture, therapeutic massage, household services, handicrafts, flower arrangement, rug weaving, painting, and the performing arts such as music and dance." Due to the nature of labor being involuntary, the cheap production of goods manufactured in XUAR-run facilities enhances its financial capacities. Besides, the Bingtuan is also involved in the construction sector (Potter 2011), which has profited from the boom in detention centers in 2017 and 2018.

\section{The Security Sector}

Companies linked to the security sector also stand to profit from the bad human rights situation. The region's high spending on security surfaced in government bids for Artificial Intelligence and construction projects (Financial Times 2018). However, companies outside of the classical defense and security industry also benefit from the detainment camps and human rights infringement, as the repression of Uyghurs and other minorities increasingly involves sophisticated technologies such as AI or big data (compare: Office of the Central Cyberspace Affairs Commission 2017). This is in line with a Reuters report which suggests the security spending of the province is soaring and opening opportunities to companies investing in the region (Wen and Auyezov 2018; Financial Times 2018).

Companies maintaining business ties to the authorities benefit in two aspects. On the one hand, they get access to lucrative government procurement. On the other hand, companies promoting AI technologies can use the province as a testing field for developing new technologies, as they have nearly unrestricted access to data. The Chinese company Dahua, for example, has developed advanced hardware to build an AI-powered video recorder called DeepSense, which can compare 100,000 faces (ibid.). The access to databases is essential for improving and designing AI solutions for application in other contexts. Chinese websites have also noted the cooperation with local universities in the realms of AI and big data (Sina Corporation 2017). 


\section{Access of These Groups to Decision-Making}

The mentioned groups, which are interested in prolonging the system of forced labor and the detention camps, also have access to the central power. This applies explicitly to the Bingtuan. Due to the pronounced role of the military in Xinjiang, the strong power of state-owned enterprises, and the rift between the Han Chinese economy and the Uyghur economy, the local government has to pay heed to the interests of the local monopolies and is therefore likely to continue to pressure the Uyghur population. The role of the Bingtuan is extraordinarily important, as it maintains direct ties to decisionmakers in the province. The Party leader of the XUAR is also chairman of the XPCC, which illustrates the strong ties between both organizations and the prominent role of the XPCC within the political decision-making processes. Moreover, Chinese companies are based in the mainland profit from Xinjiang's securitization. The interests of these companies, however, might be more relevant on the national level, rather than on the level of the XUAR. The government spending has significantly increased over the past years, empowering Chinese businesses to develop their AI solutions by using data from Uyghurs and by having access to lucrative government procurement.

\section{Foreign Involvement}

Due to the strong connection between different forms of exploitation and human rights abuses, foreign enterprises trading or partnering with regime-affiliated entities are involved in the exploitation of Uyghurs.

\section{Foreign Direct Investment in Xinjiang}

It appears that the Chinese government desires cooperation with foreign entities. The reason behind this is twofold. On the one hand, foreign enterprises require Han Chinese specialists from other provinces. This complies with the larger strategy to increase the Han Chinese share as part of the total population of Xinjiang (Bao 2018). The intentions of the Chinese government to lure investors to invest in China's Far West are therefore motivated not only by purely economic considerations but also by efforts to consolidate Beijing's grip on Xinjiang. On the other hand, the investment of foreign entities supports the Chinese narrative that things in Xinjiang are "normal." In order to proceed with this goal, the Chinese government has set up institutions such as the Xinjiang Association of Enterprises with Foreign Investment, which coordinates investment projects. International companies investing in the region include, for example, Coca Cola, Volkswagen, Siemens, and BASF (Dou and Deng 2019; Buckley and Wong 2019). Reports suggest that, at least in the case of Volkswagen, the company was pushed into making business in order to secure business deals elsewhere in China. From this perspective, China has used its bargaining power to "attract FDI" in the region.

\section{Investment of Xinjiang-Affiliated Entities Abroad}

Moreover, the Xinjiang Production and Construction Corps has been involved with foreign entities abroad. According to the Chinese Foreign Ministry (MOFCOM 2019), XPCC had 
its foreign contract projects complete a turnover of US\$29.19 million in 2005 and has ramped up its foreign activities in neighboring countries and the Post-Soviet space. The XPCC has, for example, tried to negotiate a land grab in Ukraine. These measures might be linked to the attempt of solidifying the finances of the Bingtuan (c.f. Yuzhe and Jia 2018) and to finance the supervision of Uyghurs and other ethnic minorities.

\section{Trade in the Textile Industry}

In addition, trade seems to play a major role, as the low costs of labor - in the detention camps and in affiliated enterprises in the textile and agricultural industry-make exports more lucrative. Adidas, Unilever, and Nestlé are among international companies scrutinized for forced labor in the textile supply chain due to their import of textiles or cotton from China. Reports of companies potentially involved in Xinjiang have also drawn attention to supply chains of Western companies in food production (Buckley and Ramzy 2018; Zenz 2019; Dou and Deng 2019). Forced labor might also involve further business sectors. This might even follow the economic rationale of local decision-makers: Given the strong size of the state sector and the inefficiencies coming along with centralization and securitization, increasing exports and generating revenue are of more crucial importance. Cooperating with foreign entities, therefore, makes sense, as it builds a bridge between Xinjiang and markets abroad and as it exploits China's comparative advantage in the textile industry (Buckley and Ramzy 2018; Zenz 2019).

\section{Cooperation with Companies in the AI Sector}

The cooperation with foreign entities also concerns the proliferation of supervision technologies. In 2019, Siemens was accused of cooperating with Chinese companies developing security technologies (Dou and Deng 2019). The same could also apply to the cooperation of Western universities with Chinese research institutions in the region, like the Massachusetts Institute of Technology, which has been scrutinized for cooperating with Chinese companies affiliated with the police in China's Xinjiang region (Harney 2019). In a similar way, the cooperation between foreign research institutions and Chinese state agents ranging from the central government to universities often relates to the enhancement of AI and smart cities. The exposure of the situation in Xinjiang has prompted many institutions to review their ties to the Xinjiang-affiliated authorities involving the collaboration in supervision technologies and smart city concepts. The extent of these revisions illustrates that the Chinese government has heavily relied on collaboration with foreign universities, including renowned institutions such as Cornell University or MIT.

\section{International Cooperation in the Security Sector}

The Chinese government relies not only on cooperation with the state but also on the exchange within supranational organizations. On a state-to-state level, the Shanghai Organization of Cooperation involves the security services of China, Russia, Kazakhstan, Uzbekistan, and other Central Asian states and has been used as a vehicle of the persecution of Uyghurs abroad. The Chinese Government's recent White Paper 
on Xinjiang has laid a strong emphasis on the role of cooperation between foreign entities and the regional anti-terror structure. Moreover, the Bishkek Declaration of the $S C O$ recently stressed that "the Member States will counter the use of information and communications technology to undermine political, economic and public security in the SCO countries, and curb propaganda of terrorism, separatism and extremism online."

\section{What Do We Want to Do About Xinjiang?}

As seen in the normative part of our contribution, human rights entail obligations for States and enterprises. At the same time, we have seen that the ongoing issues in Xinjiang constitute violations of human rights, obliging States and enterprises to engage in measures to stop the ongoing situation. The main question is what measures need to be taken by which actors in order the situation on the ground for the better.

\section{Overall Rationale of Measures}

In literature on sanctions, it is debated whether sanctions have a punitive or preventive purpose (Committee on Legal Affairs and Human Rights of the Council of Europe 2007). The importance of a punitive character notwithstanding, we follow the argument that coercive measures imposed on the human rights violators should be seen as successful "if they affect the calculus of decision-making" (Baldwin 1985; cf. Gordon 2011) and if they are "aimed at preventing (...) gross human rights violations" (van der Have 2020). This connects to literature in political science, which posits that cost-benefit calculations - including reputational effects - matter also for political entities (Bueno de Mesquita 2002). The promise of the Chinese government to distribute growth among the crucial groups would be one of these factors. Based on these assumptions, we derive two preconditions for a successful implementation of sanctions:

- The influence of the faction advocating a tougher handling of the "Uyghur question" for example the local government needs to become weaker, whereas the power of those elements of the regime advocating human rights compliance needs to rise.

- Measures imposed on Xinjiang need to render the income model of entities involved in human rights violations - in particular in forced labor-unprofitable.

Based on the idea of sanctions as instruments of change, measures taken against the entities in Xinjiang might be derived from the duties of States and responsibilities of enterprises emerging from United Nations Guiding Principles on Business and Human Rights.

\section{Actions by States}

The discussion of coercive measures reducing the benefits of human rights complicity entails questions relating to the sanctioning party, the scope of sanctions, and the effects on third parties. 
Unilateral vs. Multilateral The first question concerns the critical mass, which is needed to have a decisive influence on Chinese policymakers. Although some studies (Biglaiser and Lektzian, 2011) support the argument that sanctions have an effect on investor decision-making, unilateral sanctions appear to trigger an increase in investment of third parties. In other words, if country A would sanction country B, country C, which evades participation in sanctions, might even stand to profit from exclusive access to trade and investment. Other studies however highlight that multilateral sanctions are less likely to result in policy changes (Kaempfer and Lowenberg 1999), hinting at a trade-off between the high impact of multilateral sanctions on trade and higher effectiveness of unilateral sanctions on political changes. Applied to the situation in Xinjiang, multilateral sanctions are less likely given China's close collaboration with other regional players (SCO) and its seat in the UN Security Council, so that the strength of sanctions will largely depend on measures taken by Western countries.

Comprehensive vs. Smart The second question addresses whom to sanction. Here, we argue that indiscriminate sanctions, which do not distinguish between involved and uninvolved entities, might produce a negative effect. The history of UN sanctions and the usage of boycott measures to enforce human rights have shown that comprehensive and indiscriminate sanctions often fail to reach their goal and come with a high cost for specific parts of the population (Hufbauer et al. 1990; Levy 1999; McMahon 2006; Powell 2014). Moreover, studies have highlighted that the prohibition of dual use goods has heavily impacted the living standards of the population, the health sector, and academic exchange (Peksen 2009; Peksen and Drury 2010). Comprehensive sanctions might even backfire against the Uyghurs, as research on the impact of sanctions on ethnic minorities (Peksen 2014) and worsen civil society development through their disproportionate impact on civilians (Cortright and Lopez 2000; Reinisch 2001). This links up to the current discussion on smart sanctions, which aim at reducing side effects on vulnerable groups and target culpable legal persons and their business interests (Drezner 2011; Joy Gordon 2011). One currently discussed (Firestone and Contini 2018; van der Have 2020) example of a smart sanctions mechanism is the Global Magnitsky Act, which allows the US administration to impose sanctions on any foreign entity which "is responsible for extrajudicial killings, torture, or other gross violations of internationally recognized human rights." (Global Magnitsky Act SEC. 1263). Although empirical evidence on the efficacy of individual sanctions remains poor (Portela 2018), the Global Magnitsky Act could entail different reputational and financial consequences for the political elites in China and Xinjiang (compare: Firestone and Contini 2018). Given the precarious economic situation of many Xinjiang-affiliated entities such as the XCPC (Bao 2018; Independent 2019), imposing financial sanctions and trade restrictions could hit entities profiting from human rights violations. This would include negative consequences for companies in the technology sector and state-owned Chinese enterprises, which provide the local government with material or technological support. The aspect of logistical challenges raised in context with smart sanctions (cf. Drezner 2011; Gordon 2011) would be less relevant for the Xinjiang case, given the use of recent technologies to analyze the patterns of human rights violations (Thum 2018). In addition, imposing visa restrictions on Chinese officials directly involved in human rights violations such as the local government in Xinjiang would affect their personal interests more than other more measures, as 
Chinese officials often have immediate relatives living abroad and significant foreign assets. The remaining and perhaps unavoidable problem is here rather that the definition of human rights violations depends on the permission of the US government, so that the consequent implementation of measures remains arbitrary and depends on political considerations (van der Have 2020).

Measures Beyond Sanctions Alternatively, coercive measures on individual entities could be based on already-existing legislation on due diligence measures in the supply chain of multinationals. One example would be the UK Modern Slavery and Human Trafficking Act, which calls on companies to disclosure slavery and forced labor in their supply chains (cf. Wen 2016; Nolan \& Bott 2018; LeBaron \& Rühmkorf 2017), leading to an exposure of entities directly or indirectly involved in the exploitation of Uyghurs. The advantage would be that extraterritorial legislation of this sort would cover also smaller entities involved in forced labor, which slip under the radar of formal sanction frameworks, and address the textile or construction industry in Xinjiang, which is involved in human rights violations. However, literature on the UK Modern Slavery and Human Trafficking Act identifies that the Modern Slavery Act appears to be "too weak in tackling modern slavery by businesses in their supply chains" (Mantouvalou 2018; cf. LeBaron \& Rühmkorf 2017). Given the absence of criminal liability and the low number of actual cases brought to court, we see therefore little potential in these measures to increase the pressure on corporate decision-makers. Using this form of legislation would require shifting the focus from disclosure to exclusion of human rights violations and by scaling up penalties for non-compliance including "initial warnings, fines (as a percentage of turnover), court summons and directors' disqualification." (Independent Review of the Modern Slavery Act 2015: Final Report 2019).

\section{Actions by Companies}

Given the difficulties of coercive measures by States, enterprises might be left alone with the decision whether to remain or to retreat from Xinjiang. International companies might even constitute an important actor to fill the void left by states (cf. Gordon 2011), as (the coordinated) divestment of companies could impose reputational and financial costs on Chinese decisionmakers comparable to formal sanctions.

The United Nations Principles on Business and Human Rights define the responsibilities of companies in terms of avoiding "causing or contributing to adverse human rights impacts". Given the absence of strong legal provisions for corporations at present, the implementation of the normative principles laid out by the document depends on the good will and on reputational effects of noncompliance with human rights standards (cf. Spar 1998; Garriga 2016). Moreover, the UNGPs remain rather vague for the case, when companies are "faced with conflicting requirements" (UNGPs 23/1) and are not binding in the legal sense. The wording of "seek ways to honour the principles of internationally recognized human rights" might therefore be linked with business ethics literature on the obligations of multinationals in authoritarian regimes 
(cf. Santoro 2000; Sethi and Williams 2002). ${ }^{2}$ This begs the question, whether foreign companies should suspend business operations with and in Xinjiang or not (compare White 2004; Holliday 2005). Given the asymmetry of power between multinationals and the Chinese government, which differs from Myanmar, Sudan, and arguably China in the 1990s (cf. Santoro 2000), companies have a very limited negotiating space to realize policies promoting Uyghurs. As result, leaving the region might depict the only option avoiding complicity in human rights violations (cf. Clapham and Jerbi 2001; White 2004). This applies in specific to companies with high risk of forced labor in the supply chain-such as the textile industry ${ }^{3}$ - and business operations with close business ties with the local administration and state-owned enterprises.

\section{Conclusion}

In the normative part, we dealt with the status of human rights within international law. We argue that human rights derive their normative status from customary international law and that they do not only apply to the signatory parties of international human rights regimes. Moreover, human rights bind not only States but also multinationals.

The analysis of the situation in Xinjiang shows that the indiscriminate incarceration of a large part of the Uyghur population and the erection of detainment camps contravenes the idea of human rights and fundamental standards of international law. Overarching security interests and the will of the Chinese leadership to tighten the grip on the strategically relevant region motivate these actions. On the local level, special interest groups stand to profit from the disenfranchisement of the Uyghur population and other ethnic groups ranging from expropriation, labor market discrimination, public procurement, and an increased spending for the securization of the region.

Understanding this political economy of human rights violations in Xinjiang is helpful for determine the right measures to fulfill the normative obligations. One way could be international sanctions, which aim at increasing the financial and reputational costs on the entities profiting from the status quo. Policymakers however need to be aware of two factors, when calling for sanctions. An international consensus on the Xinjiang issue is unlikely given China's weight in the international arena. Comprehensive sanctions might backfire against the Uyghur population, as they do not distinguish between human rights violators and innocent bystanders. Based on these two constraints, we propose the enhancement of smart sanction frameworks such as the Global Magnitsky Act and legislation on supply chain due diligence such as the UK Modern Slavery and Human Trafficking Act. Each alternative has its flaws: While the Global Magnitsky Act is not free from political considerations, supply chain legislation needs to be stepped up significantly, given the low likelihood for penalties

\footnotetext{
${ }^{2}$ These measures could be comparable to Xinjiang-specific "Sullivan Principles" or to other precautions, which aim at promoting Uyghurs economically and socially (cf. Santoro 2000; Sethi and Williams 2002).

${ }^{3}$ International organizations such as the World Bank have begun to reconsider their involvement in Xinjiang, while textile manufacturers including Adidas or Badger Sportswear have withdrawn from Xinjiang (Buckley and Ramzy 2018; Dou and Deng 2019). Divestment also concerns collaboration in the realm of AI and digital technologies, and some enterprises (Murgia and Shepherd 2019) have decided to discontinue the handover of technologies and knowledge to Chinese entities involved in the humna rights violations in Xinjiang.
} 
in case of misconduct. Moreover, we identify that the scope of both measures might be different as formal sanctions are useful to address state organizations and affiliated state enterprises, whereas extraterritorial legislation focuses rather on business sectors with high risks of forced labor and smaller entities.

As of now, the human rights responsibilities of companies arising from the UNGP remain rather vague. This applies in specific to when local laws and international human rights treatises conflict with each other in the case of Xinjiang. To cope with these situations, we propose to enrich the discourse by integrating frameworks such as the Global Sullivan Principles or the fair share theory of Santoro (2002) in the UNGPs. We conclude that a supportive legal infrastructure remains necessary for defining proper conduct in situations comparable to the events going on in Xinjiang and for interpreting the human rights responsibilities of companies.

Funding Open Access funding enabled and organized by Projekt DEAL.

Open Access This article is licensed under a Creative Commons Attribution 4.0 International License, which permits use, sharing, adaptation, distribution and reproduction in any medium or format, as long as you give appropriate credit to the original author(s) and the source, provide a link to the Creative Commons licence, and indicate if changes were made. The images or other third party material in this article are included in the article's Creative Commons licence, unless indicated otherwise in a credit line to the material. If material is not included in the article's Creative Commons licence and your intended use is not permitted by statutory regulation or exceeds the permitted use, you will need to obtain permission directly from the copyright holder. To view a copy of this licence, visit http://creativecommons.org/licenses/by/4.0/.

\section{References}

Appiah MK, Feike T, Wiredu AN, Mamitimin Y (2014) Cotton Production, Land Use Change and Resource Competition in the Aksu-Tarim River Basin, Xinjiang, China. Quarterly Journal of International Agriculture 53(3): 243-261. https://doi.org/10.22004/ag.econ.195737

Baderin MA (2003) International Human Rights and Islamic Law. Oxford University Press, Oxford.

Baldwin DA (1985) Economic Statecraft. Princeton University Press, Princton, NJ.

Bao Y (2018) The Xinjiang Production and Construction Corps: An Insider's Perspective, Link: blogs.bsg.ox.ac. uk/2018/02/02/the-xinjiang-production-and-construction-corps-an-insiders-perspective/ Accessed 27 March 2020

Becquelin N (2004) Staged development in Xinjiang. The China Quarterly 178:358-378. doi.org/10.1017 /S0305741004000219

Biglaiser, G. and Lektzian, D. (2011) The Effect of Sanctions on U.S. Foreign Direct Investment. International Organization, 65(3), 531-551. https://doi.org/10.1017/S0020818311000117

Buckley C, Ramzy A (2018) China's Detention Camps for Muslims Turn to Forced Labor. The New York Times. nytimes.com/2018/12/16/world/asia/xinjiang-china-forced-labor-camps-uighurs.html. Accessed 28 March 2020

Buckley C, Wong E (2019) Doubt Greets China's Claim That Muslims Have Been Released From Camps. The New York Times. nytimes.com/2019/07/30/world/asia/china-xinjiang.html. Accessed 28 March 2020

Bueno de Mesquita B (2002) Predicting Politics. Ohio State University Press, Columbus.

Buergenthal T (1976) The Evolving International Human Rights System, The American Journal of International Law 100:4, 783-807.

Caplan LM (2003) State Immunity, Human Rights, and Jus Cogens: A Critique of the Normative Hierarchy Theory. 97 AM. J. INT'L L. 741: 745-65.

China Daily (2019). Vocational Education and Training in Xinjiang. http://english.www.gov. cn/archive/whitepaper/201908/17/content_WS5d57573cc6d0c6695ff7ed6c.html Accessed 20 March 2020

Clapham A and Jerbi S (2001) Categories of Corporate Complicity in Human Rights Abuses. in: Hastings International and Comparative Law Review 24: 339-50. 
Cliff T, James M (2007) Neo Oasis: The Xinjiang Bingtuan in the Twenty-first Century. Asian Studies Review 33:83-106. https://doi.org/10.1080/10357820802714807

Cohen R, Deng FM (1998) Masses in Flight: The Global Crisis of Internal Displacement, Brookings Institution Press: Washington, DC.

Committee on Legal Affairs and Human Rights of the Council of Europe (2007) United Nations Security Council and European Union Blacklists, Report for the Parliamentary Assembly, available at: assembly. coe.int/nw/xml/XRef/X2H-Xref-ViewHTML.asp?FileID=11749, para 4 Accessed 28 March 2020.

Corlatean T (2019) The Incompatibility of the Sharia Law and the Cairo Declaration on Human Rights in Islam with the European Convention on Human Rights (April 25 2019). RAIS Conference Proceedings - The 12th International RAIS Conference on Social Sciences \& Humanities. https://oi.org/10.2139/ssrn.3387907

Cortright D, Lopez GA (2000) Sanctions Decade: Assessing U.N. Strategies in the 1990s. Lynne Rienner Publishers, Boulder, C.O.

Cragg W (2000) Human Rights and Business Ethics: Fashioning a New Social Contract. In: Journal of Business Ethics 27(1): 205-14.

Crawford J and Keene A (2019) Interpretation of the human rights treaties by the International Court of Justice. in: The International Journal of Human Rights. DOI: https://doi.org/10.1080/13642987.2019.1600509.

D'Amato A (2010) Human Rights as Part of Customary International Law: A Plea for Change of Paradigms. Faculty Working Papers. 88.

Dashti-Gibson J, Davis P, Radcliff B (1997) On the Determinants of the Success of Economic Sanctions: An Empirical Analysis. American Journal of Political Science 41(2):608-618. doi:https://doi.org/10.2307/2111779

De Bakker FGA, De Hond F (2010) A Disputed Contract: IHC Caland in Burma. In: Dubbink W., van Liedekerke L, van Luijk H (eds.) European Business Ethics Casebook. Issues in Business Ethics 29. Springer: Dordrecht.

De Hoogh A (1996) Obligations Erga Omnes and International Crimes. Kluwer law international, The Hague.

De Jong F (2017) Uyghur Texts in Context: Life in Shinjang Documented from Public Spaces. Koninklijke Brill NV: Leiden. https://oi.org/10.1163/9789004354029.

Delacote P (2009) On the sources of consumer boycotts ineffectiveness, Journal of Environment and Development 18(3):306-322. https://doi.org/10.1177/1070496509338849

Donaldson T, Dunfee T (1999) When ethics travel: the promise and peril of global business ethics. California Management Review 41(4): 45-63.

Donnelly J (1984) Cultural Relativism and Universal Human Rights. Human Rights Quarterly 6(4):400-419. https://doi.org/10.2307/762182

Dou E, Deng C (2019) Western Companies Get Tangled in China's Muslim clampdown. The Wall Street Journal. wsj.com/articles/western-companies-get-tangled-in-chinas-muslim-clampdown-11558017472 Accessed 28 March 2020

Drezner DW (2011) Sanctions Sometimes Smart: Targeted Sanctions in Theory and Practice. in: International Studies Review, 13 (1): 96-108. doi.org/10.1111/j.1468-2486.2010.01001.x

Economist (2017) A provincial shuffle shows the power of China's president. https://www.economist. com/china/2017/05/27/a-provincial-shuffle-shows-the-power-of-chinas-president Accessed 27 March 2020

Economist (2018) China has turned Xinjiang into a police state like no other. economist.com/briefing/2018/05 /31/china-has-turned-xinjiang-into-a-police-state-like-no-other Accessed 27 March 2020

European External Action Service (2018) Speech on behalf of the High Representative/Vice-President Federica Mogherini at the European Parliament urgency debate on Mass arbitrary detention of Uyghurs and Kazakhs in the Xinjiang Uyghur Autonomous Region eeas.europa.eu/headquarters/headquartershomepage/51670/speech-behalf-high-representativevice-president-federica-mogherini-europeanparliament-urgency_en Accessed 27 March 2020

Feng Y (1997). Democracy, Political Stability and Economic Growth. British Journal of Political Science, 27(3), 391-418.

Feng E (2018) Security spending ramped up in China's restive Xinjiang region. ft.com/content/aa4465aa2349-11e8-ae48-60d3531b7d11

Financial Times (2018) Crackdown in Xinjiang: Where have all the people gone? $\mathrm{ft.com} / \mathrm{content} / \mathrm{ac0ffb} 2 \mathrm{e}-$ 8b36-11e8-b18d-0181731a0340 Accessed 27 March 2020

Firestone T, Contini K (2018) The Global Magnitsky Act. Criminal Law Forum 29: 617-628 (2018). doi. org/10.1007/s10609-018-9353-Z

Foreign Policy (2014) China's Vast, Strange, and Powerful Farming Militia Turns 60 foreignpolicy.com/2014 /10/08/chinas-vast-strange-and-powerful-farming-militia-turns-60/ Accessed 27 March 2020

Foreign Policy (2019) China's Paramilitary Police Could Crush Hong Kong, foreignpolicy.com/2019/08/06 /chinas-paramilitary-police-could-crush-hong-kong/ Accessed 27 March 2020 
Frank TM (1997) Is Personal Freedom a Western Value? American Journal of International Law 91(4):593627. https://doi.org/10.2307/2998096

Garriga AC (2016) Human Rights Regimes, Reputation, and Foreign Direct Investment International Studies Quarterly 60(1): 160-72.

Gilabert P (2011) Humanist and Political Perspectives on Human Rights. Political Theory 39(4):439-467.

Girardet E (2012) Afghanistan: The Soviet War. Routledge Revivals. Routledge, London.

Goldsmith J (2000) Should International Human Rights Law Trump US Domestic Law? in: Chicago Journal of International Law 1(2): 327-339.

Goodman DSG (1980) The Provincial First Party Secretary in the People's Republic of China 1949-78: A Profile. British Journal of Political Science 10(1):39-74. https://doi.org/10.1017/S0007123400002003

Gordon J (2011) Smart Sanctions Revisited. in: Ethics \& International Affairs 25(03) :315 - 335.

Grauvogel J Von Soest C (2014) Claims to legitimacy count. European Journal of Political Research 53:635653. https://doi.org/10.1111/1475-6765.12065

Haas RN (1998) Economic Sanctions: Too Much of a Bad Thing. Brookings. brookings.edu/research/ economic-sanctions-too-much-of-a-bad-thing/ Accessed 19 Oct 2019.

Habermas J (1994) Human Rights and Popular Sovereignty: The Liberal and Republican Versions. Ratio Juris 7(1):1-13.

Harney A (2019) Risky partner: Top U.S. universities took funds from Chinese firm tied to Xinjiang security. Reuters reuters.com/article/us-china-xinjiang-mit-tech-insight/risky-partner-top-u-s-universities-tookfunds-from-chinese-firm-tied-to-xinjiang-security-idUSKCN1TE04M Accessed 28 March 2020

Henkin L (1995/1996) Human Rights and State Sovereignty. Sibley Lecture/Keynote Address. in: Georgia Journal of International and Comparative Law 25 (1 \& 2): 31-46.

Holliday I (2005) Doing Business with Rights-Violating Regimes: Corporate Social Responsibility and Myanmar's Military Junta. Journal of Business Ethics 61(4): 329-42.

Hong JY Wenhui Y (2018) Oilfields, Mosques and Violence: Is There a Resource Curse in Xinjiang?. British Journal of Political Science 1-34. doi.org/10.1017/S0007123417000564

Hoshur S (2015) Forced labor for Uyghurs in Xinjiang county to promote 'stability'. Radio Free Asia. rfa. org/english/news/uyghur/labor-06092015171123.html Accessed 27 March 2020

Hsieh N (2015) Should Business Have Human Rights Obligations? in: Journal of Human Rights 14(2): 218-36.

Hufbauer GC, Schott JJ, Elliott KA (1990) Economic Sanctions Reconsidered: History and Current Policy, 2nd Edition, Washington D.C.: Institute for International Economics 1990.

Hufbauer GC, Schott JJ, Elliott KA, Oegg B (2012) Economic Sanctions reconsidered: History and Current Policy, 3rd edition, Peterson Institute, November 2007, with updates on US v. Iran case study of early 2012.

Independent (2019) World Bank launches investigation into whether £40m loan to China funds Muslim persecution in detention centres. independent.co.uk/news/world/asia/world-bank-loan-china-xinjianguighur-muslim-detention-camps-a9086491.html Accessed 27 March 2020

Independent Review of the Modern Slavery Act 2015: Final Report (2019) assets.publishing.service.gov. uk/government/uploads/system/uploads/attachment_data/file/803406/Independent_review_of_the_ Modern_Slavery_Act__final_report.pdf Accessed 28 March 2020.

International Commission on Intervention and State Sovereignty [ICISS] (2001) The Responsibility to Protect. responsibilitytoprotect.org/ICISS\%20Report.pdf Accessed 28 March 2020.

International Court of Justice (1970) Barcelona Traction, Light and Power Company Case. ICJ Reports. icj-cij. org/files/case-related/50/050-19700205-JUD-01-00-EN.pdf Accessed 27 March 2020

Jägers N (2002) Corporate Human Rights Obligations: In Search of Accountability. Intersentia: Antwerp.

Jones C (2018) Concepts of Sovereignty Their Evolution and Status. in: China's Challenge to Liberal Norms. Palgrave Macmillan: London.

Kaempfer W, Lowenberg AD (1999) Unilateral Versus Multilateral International Sanctions: A Public Choice Perspective. In: International Studies Quarterly 43(1): 37-58. doi.org/10.1111/0020-8833.00110

Kaempfer W, Lowenberg AD (2007) The Political Economy of Economic Sanctions. Handbook of Defense Economics 2:867-911.

Lauterpacht H (1950) International Law and Human Rights. Stevens: London.

LeBaron G, Rühmkorf A (2017) Steering CSR Through Home State Regulation: A Comparison of the Impact of the UK Bribery Act and Modern Slavery Act on Global Supply Chain Governance. in: Glob Policy, 8: 15-28. https://doi.org/10.1111/1758-5899.12398

Levy PI (1999) Sanctions on South Africa: What Did They Do? American Economic Review 89(2): 415-420.

MacDonald, Stephen, Gale, Fred and Hansen, James. Cotton Policy in China. ers.usda. gov/webdocs/publications/36244/52550_cws-15c-01.pdf?v=0, CWS-15c-01 March 2015, Accessed,

Mantouvalou V (2018) The UK Modern Slavery Act 2015 Three Years On. In: The Modern Law Review, 81: 1017-1045. doi:https://doi.org/10.1111/1468-2230.12377. 
McCrudden C (2015) Why Do National Court Judges Refer to Human Rights Treaties? A Comparative International Law Analysis of CEDAW, American Journal of International Law 109(3): 534-550.

McDougal MS, Reisman WM (1983) International Law in Policy-Oriented Perspective. The Structure and Process of International Law: Essays in Legal Philosophy, Doctrine and Theory. International Law in Policy Oriented Perspective. eds. Macdonald RSJ, Johnston DM. Martinus Nijhoff Publishers, Leiden.

McMahon R (2006) UN Sanctions: A Mixed Record cfr.org/backgrounder/un-sanctions-mixed-record Accessed 27 March 2020

MOFCOM (2019) Doing Business in XPCC. Ministry of Commerce of the People's Republic of China. english.mofcom.gov.cn/aroundchina/xinjiangbingtuan.shtml Accessed 28 March 2020

Mohanty M (2003) CPC's Fourth Generation Ideology. Economic and Political Weekly 38(14):1365-1369.

Murgia M, Shepherd C (2019) US universities reconsider research links with Chinese AI company. https://www.ft.com/content/2f1 12da0-8e19-11e9-a1c1-51bf8f989972 Accessed 28 March 2020

Murphy T, Johnson P (2004) Torture and Human Rights. Virtual Mentor 6(9):420-423. doi.org/10.1001 /virtualmentor.2004.6.9.oped1-0409

Nolan J, Bott G (2018) Global supply chains and human rights: spotlight on forced labour and modern slavery practices. in: Australian Journal of Human Rights, 24:1, 44-69, DOI: https://doi.org/10.1080/1323238 X.2018.1441610.

North D. (1981). Structure and Change in Economic History. Norton: New York.

North D (1991) Institutional Change: A Framework of Analysis. econwpa.ub.uni-muenchen.de/econ-wp/eh/ papers/9412/9412001.pdf Accessed 27 March 2020

OECD (2018) China's Belt and Road Initiative in the Global Trade, Investment and Finance Landscape. OECD Business and Finance Outlook 2018, OECD Publishing, Paris, doi.org/10.1787/bus_fin_out-20186-en.

Office of the Central Cyberspace Affairs Commission (2017): 新疆“人工智能和视频大数据在公安业务中的应用”论 坛举行, cac.gov.cn/2017-08/24/c_1121536255.htm (in text reference: Office of the Central Cyberspace Affairs Commission 2017) Accessed 28 March 2020

Peksen D (2009) Better or Worse? The Effect of Economic Sanctions on Human Rights. in: Journal of Peace Research 46(1): 59-77.

Peksen D, Drury AC (2010) Coercive or Corrosive: The Negative Impact of Economic Sanctions on Democracy. in: International Interactions, 36:3, 240-264, DOI: https://doi.org/10.1080 /03050629.2010.502436.

Peksen D (2016) Economic sanctions and official ethnic discrimination in target countries, 1950-2003, Defence and Peace Economics, 27:4, 480-502 https://doi.org/10.1080/10242694.2014.920219

Perper R (2019) Uighur activists say China is running nearly 500 detention camps and prisons in Xinjiang based on satellite images. Business Insider businessinsider.de/uighur-activists-satellite-images-china-500camps-prisons-in-xinjiang-2019-11?r=US\&IR=T Accessed 28 March 2020

Portela C (2018) Targeted Sanctions Against Individuals on Grounds of Grave Human Rights Violations Impact, Trends and Prospects at EU Level', Study for the European Parliament, PE603.869, available at: europarl.europa.eu/thinktank/en/ document.html?reference=EXPO STU\%282018\%29603869 Accessed 27 March 2020

Potter P (2011) Law, Policy, and Practice on China's Periphery: Selective Adaptation and Institutional Capacity. Routledge, London.

Powell B (2014) A Case Against Child Labor Prohibitions. Cato Institute Economic Development Bulletin. Nr. 21. July 2014.

Rabkin J (1998) Why Souvereignty Matters. American Enterprise Institute for Public Policy Research, Washington, D.C.

Radio Free Asia (2013) Farmers Complain of Land Grabbing, Corruption in Xinjiang Village. Radio Free Asia. rfa.org/english/news/uyghur/farm-06032013205126.html Accessed 28 March 2020

Radio Free Asia (2019) For Xinjiang's Uyghurs, 'Hashar' by Any Other Name Still Means Forced Labor. Radio Free Asia. rfa.org/english/news/uyghur/for-xinjiangs-uyghurs-hashar-02162017112652.html Accessed 28 March 2020

Rawls J (2001) The Law of Peoples. Harvard University Press, Columbia.

Reinisch A (2001) Developing Human Rights and Humanitarian Law Accountability of the Security Council for the Imposition of Economic Sanctions. In: American Journal of International Law, 95(4), 851-872. doi:https://doi.org/10.2307/2674632.

Reisman WM (1990) Sovereignty and Human Rights in Contemporary International Law. The American Journal of International Law 84(4):866-876. doi.org/10.2307/2202838

Rosas A (1995) State Sovereignty and Human Rights: towards a Global Constitutional Project. in: Political Studies 43: 61-78. 
Roth B (2004) The enduring significance of state souvereignty. Florida Law Review 56: 1017-1049.

Ruggie JG (1993) Territoriality and Beyond: Problematizing Modernity in International Relations, in: International Organization 47(1):139-174. doi.org/10.1017/S0020818300004732

Ryan F, Cave D, Ruser N (2018) Mapping Xinjiang's 're-education' camps. ASPI. https://www.aspi.org. au/report/mapping-xinjiangs-re-education-camps Accessed 28 March 2020

Santoro MA (2000) Profits and Principles: Global Capitalism and Human Rights in China. Cornell University Press: Ithaca, NY.

Sen A (1999) Democracy as a Universal Value. Journal of Democracy 10(3): 3-17.

Sethi SP, Williams O (2002) Creating and Implementing Global Codes of Conduct: An Assessment of the Sullivan Principles as a Role Model for Developing International Codes of Conduct-Lessons Learned and Unlearned. in: Business and Society Review 105(2): 169-200.

Seymour JS, Anderson R (1999) New Ghosts, Old Ghosts: Prisons and Labor Reform Camps in China. Routledge, London.

Simma B, Alston P (1992) The Sources of Human Rights Law: Custom, Jus Cogens, and General Principles. In: The Australian Year Book of International Law Online 12(1): 82-108.

Sina Corperation (2017) 新疆“人工智能和视频大数据在公安业务中的应用”论坛举行, news.sina.com.cn/c/2017-0818/doc-ifykcirz2926253.shtml Accessed 28 March 2020

Slaughter AM, Burke-White WW (2006) The Future of International Law is Domestic (or, The European Way of Law). Faculty Scholarship. Paper 962 47(2).

Smeets M (2018) Can economic sanctions be effective?, WTO Staff Working Paper, No. ERSD-2018-03, World Trade Organization (WTO), Geneva.

Spar DL (1998) The Spotlight and the Bottom Line: How Multinationals Export Human Rights. Foreign Affairs 77(2): 7-12.

Stacy H (2003) Relational Sovereignty. in: Stanford Law Review 55(5): 2029-2059.

Starr F (2003) Editor Xinjiang: China’s Muslim Frontier. M.E. Sharpe, New York.

Tang W (2016) Populist Authoritarianism: Chinese Political Culture and Regime Sustainability. Oxford University Press, New York.

Thum R (2018) China's Mass Internment Camps Have No Clear End in Sight. Foreign Policy. foreignpolicy. com/2018/08/22/chinas-mass-internment-camps-have-no-clear-end-in-sight/ Accessed 28 March 2020

UN OHCHR (2019) Counter-Terrorism Law of the People's Republic of China and its Regional Implementing Measures, the 2016 Xinjiang Uyghur Autonomous Region Implementing Measures https://www.ohchr.org/Documents/Issues/Terrorism/SR/OL_CHN_18_2019.pdf Accessed 28 March 2020

United Nations Environment Programme (2002) UNEP Country Projects - Round II - A Synthesis Report https://unep.ch/etu/publications/Synth_China.PDF Accessed 28 March 2020

van der Have N (2020) The Proposed EU Human Rights Sanctions Regime, in Security and Human Rights: 116. doi.org/10.1163/18750230-02901009

Wen S (2016) The Cogs and Wheels of Reflexive Law - Business Disclosure under the Modern Slavery Act. in: Journal of Law and Society, 43: 327-359. doi:https://doi.org/10.1111/j.1467-6478.2016.00758.x.

Wen P, Auyezov O (2018) Tracking China's Muslim Gulag. Reuters. https://www.reuters. com/investigates/special-report/muslims-camps-china Accessed 28 March 2020

Wettstein F (2015) Normativity, Ethics, and the UN Guiding Principles on Business and Human Rights: A Critical Assessment. in: Journal of Human Rights 2(14): 162-182.

White J (2004) Globalization, Divestment and Human Rights in Burma. Journal of Corporate Citizenship 14: 47-65.

Wong E (2014) China Invests in Region Rich in Oil, Coal and Also Strife. The New York Times. nytimes. com/2014/12/21/world/asia/china-invests-in-xinjiang-region-rich-in-oil-coal-and-also-strife.html Accessed 28 March 2020

Yuzhe Z, Jia D (2018) Surprise Default in Xinjiang Raises New Debt Fears. Caixin Global caixinglobal. com/2018-08-15/surprise-default-in-xinjiang-raises-new-debt-fears-101315011.html Accessed 27 March 2020

Zenz A (2019) Beyond the Camps: Beijing's Grand Scheme of Forced Labor, Poverty Alleviation and Social Control in Xinjiang. SocArXiv Papers. osf.io/preprints/socarxiv/8tsk2

Publisher's Note Springer Nature remains neutral with regard to jurisdictional claims in published maps and institutional affiliations. 